Alicja JORASZ

Uniwersytet im. A. Mickiewicza, Poznań

\title{
Regulacje prawne postępowania antydumpingowego w Polsce w świetle przystąpienia do Unii Europejskiej
}

\section{Kontrowersje wokól rozwiązań prawnych dotyczących dumpingu}

Podstawowe regulacje dotyczące dumpingu i postępowania antydumpingowego zawierała początkowo ustawa z 28 grudnia 1989 roku Prawo celne (Dz. U. 1994 Nr 71, poz. 312). Jednak ustanowiony ustawą z 9 stycznia 1997 roku Kodeks celny (Dz. U. 2001 Nr 75, poz. 802) nie podejmował tej problematyki, podczas gdy istotne zmiany regulacji otoczenia międzynarodowego, jak też sytuacja handlu zagranicznego w Polsce wymuszały stworzenie nowych, odpowiednich regulacji prawnych ${ }^{1}$. Zostały one zawarte w ustawie z dnia 11 grudnia 1997 roku o ochronie przed przywozem na polski obszar celny towarów po cenach dumpingowych (Dz. U. 1997, Nr 157, poz. 1028).

Przyjęcie tej regulacji wzbudziło wiele kontrowersji w środowisku ekonomistów i zapoczątkowało dyskusję na temat zasadności wprowadzania regulacji antydumpingowych. Według profesora Bartłomieja Kamińskiego, pracownika Uniwersytetu Maryland, College Park i konsultanta Grupy Badawczej do spraw Rozwoju Gospodarczego w Banku Światowym, eksperta Centrum im. A. Smitha, ustawa antydumpingowa zawsze przynosi gospodarce więcej strat niż korzyści, którą to konkluzję zawierał także autoryzowany raport Amerykańskiej Komisji Handlu Międzynarodowego o ekonomicznych konsekwencjach ustawodawstwa antydumpingowego w Stanach Zjednoczonych ${ }^{2}$. Według profesora Kamińskiego pogląd o szkodliwości regulacji antydumpingowych podziela również większość ekonomistów, a Polski na antydumping nie stać. Autor

${ }^{1}$ B. Bernaś (praca zbiorowa), Międzynarodowe transakcje ekonomiczne, Centrum Doradztwa i Informacji Difin sp. z o.o., Warszawa 2002, s. 168.

2 B. Kamiński, Antydumping. Polska nie potrzebuje specjalnej ustawy. Więcej strat niż korzyści, ,Rzeczposopolita”, gazeta/Ekonomia, nr 272, 22-23 listopada 1997 r. 
w artykule dowodzi, że popularność ustaw antydumpingowych nie wynika z powszechności praktyk dumpingowych w handlu zagranicznym, a ustawodawstwo antydumpingowe nie jest skierowane przeciwko dumpingowi, ale przeciw konkurencji zagranicznej oraz rodzimemu konsumentowi. Nie zgadza się on z poglądami zwolenników antydumpingu, według których daje on państwu wygodne narzędzie do otwierania dostępu do zamkniętych rynków. Neguje on również zasadność twierdzenia, jakoby ustawę antydumpingową narzucała Polsce WTO i wskazuje na fakt, że żaden z ważniejszych artykułów WTO nie nakłada takiego obowiązku na państwa członkowskie, pozwalając krajom członkowskim na stosowanie różnych metod ochrony w przypadku, gdy import zagraża żywotnym interesom gospodarki bądź też gdy eksporter używa „wątpliwych” metod zdobywania rynku. Profesor Kamiński podkreśla, że wśród ekonomistów zajmujących się handlem międzynarodowym panuje zgoda co do tego, że antydumping jest najgorszym rozwiązaniem, które obniża konkurencyjność krajowych producentów na rynkach międzynarodowych oraz zwiększa ceny płacone przez konsumentów. Podnosi też obawy, że:

- obecność administracji w zarządzaniu handlem zagranicznym uległa ostatnio dość dużemu zwiększeniu, a ustawa antydumpingowa zwiększy uzależnienie państwa od niekonkurencyjnych sektorów gospodarki,

- przedsiębiorcy zamiast koncentrować się na poprawie konkurencyjności wytwarzanych przez nich produktów będą spędzać czas na negocjacjach $\mathrm{z}$ administracja,

- antydumping będzie używany jako instrument protekcji bez względu na koszty społeczne,

- w momencie, gdy Polska stanie się członkiem Unii Europejskiej decyzje w sprawach polityki zagranicznej będą podejmowane w Brukseli, a nie w Warszawie ${ }^{3}$.

Z profesorem Bartłomiejem Kamińskim polemizował na łamach „Rzeczypospolitej” Maciej Leśny, wówczas wiceminister gospodarki, przewodniczący powołanego przez premiera zespołu do spraw koordynowania prac nad aktami prawnymi kompleksowo regulującymi sprawy cel$\mathrm{ne}^{4}$. Podważał on argumenty oponenta konkludując, że profesor Kamiński „koncentrując się na antydumpingu tak naprawdę pisze o subsydiach”. Leśny w swojej polemice wskazał, że w Unii Europejskiej niektóre obsza-

3 Ibidem.

${ }^{4}$ M. Leśny, Antydumping - więcej strat niż korzyści. Powtórka z rozrywki, „Rzeczpospolita”, gazeta/Ekonomia, nr 285, 8 grudnia 1997 r. 
ry wciąż otaczane były barierami ochronnymi, a Unia Europejska była drugim po Stanach Zjednoczonych rynkiem, na którym stosowane były najwyższe cła antydumpingowe, również wobec polskich wyrobów. Ani UE, ani „,bastion wolnej konkurencji”, jakim są Stany Zjednoczone nie zamierzają rezygnować z barier ochronnych, czego przykładem jest stale rosnąca liczba postępowań antydumpingowych, która nie potwierdza tezy profesora Kamińskiego, że ,popularność ustaw antydumpingowych nie wynika zatem z powszechności praktyk dumpingowych w handlu zagranicznym".

Autor polemiki podkreśla, że Układ Stowarzyszeniowy Polski ze Wspólnotami Europejskimi nakłada obowiązek harmonizacji polskiego prawa z prawem UE, a w artykule 69 układu jako pierwszą dziedzinę do harmonizacji wymieniono szeroko pojęty obszar regulacji wymiany towarowej z zagranica. Chęć zliberalizowania światowego handlu, poprzez znoszenie ograniczeń, jest naczelną zasadą porozumienia ustanawiającego WTO. „Oczywiście nie ma nakazu stosowania zasad WTO w sensie dosłownym. W umowach międzynarodowych stosuje się bardziej subtelne metody nacisku". Autor wyjaśnia dalej, że WTO narzuciło jasne reguły budowy ustawodawstwa ochronnego, w tym antydumpingowego po to, by wszyscy bronili się przed nieuczciwą konkurencją w identyczny sposób i by procedury antydumpongowe nie były nadużywane. W Genewie przygotowano nawet szablon takiej ustawy dla krajów rozwijających się, których służby prawne nie mają takiego przygotowania. Zgodnie z WTO, państwa członkowskie wobec eksporterów pochodzących z WTO nie mogą stosować innych procedur ochronnych niż te, które są dopuszczalne w tej organizacji. Dlatego też każde państwo członkowskie po opracowaniu swoich ustaw ochronnych musi je notyfikować w WTO. Dopiero po uzyskaniu pozytywnej opinii WTO ustawa może być stosowana. Każdorazowy przypadek wszczęcia postępowania ochronnego przeciwko eksporterowi pochodzącemu z WTO musi być także zgłoszony w odpowiednim komitecie tej organizacji bądź w Komitecie Praktyk Antydumpingowych WTO, bądź to w Komitecie Środków Ochronnych WTO czy też w końcu w Komitecie Środków Wyrównawczych i Subsydiów WTO. Oczywiście państwo może się bronić przed dumpingiem lub nie i jest to tylko kwestia - co podkreśla Leśny - świadomego wyboru chociażby między kosztami prowadzenia postępowania ochronnego a kosztami obsługi bezrobocia. Polska od 1 lipca 1995 roku stała się członkiem-założycielem WTO, jednak w związku z tym, że obowiązujące od 1989 roku prawo celne zawierało procedury ochronne niezgodne ze standardami WTO, 
Polska musiała złożyć zobowiązanie, że nie będzie wszczynać postępowań ochronnych (w tym antydumpingowych) wobec krajów członkowskich WTO. Być może deficyt w polskim handlu zagranicznym byłby mniejszy, gdybyśmy mogli takie postępowanie wszczynać wcześniej, a nie dopiero od 1 stycznia 1998 roku, konkluduje Leśny ${ }^{5}$.

Do dyskusji włączył się również zastępca generalnego inspektora celnego Adam Pałafij ${ }^{6}$. Podkreśla on, że zgodnie ze stwierdzeniem zawartym w art. II ust. 2 porozumienia z 15 kwietnia 1994 roku ustanawiającego WTO, a mianowicie: „Porozumienia i związane z nimi instrumenty prawne zawarte w załącznikach 1, 2 i 3, zwane dalej wielostronnymi porozumieniami handlowymi, stanowią integralne części niniejszego porozumienia, wiążące dla wszystkich członków" porozumienie w sprawie antydumpingu należy do grupy ,wielostronnych porozumień handlowych” i niedopuszczalne byłoby uchylenie się od jego stosowania. To z kolei wymaga wydania odpowiednich krajowych przepisów implementacyjnych. Zaznacza on, że „stosowanie wielostronnych porozumień handlowych może być co najwyżej okresowo zawieszone - ale zgodnie z art. IX układu GATT 1994 - wyłącznie po uzyskaniu aprobaty trzech czwartych członków WTO. Można było zrezygnować z udziału w porozumieniu antydumpingowym, lecz należało zrobić to $\mathrm{w}$ momencie przystępowania do układu GATT 1994. Takiego zastrzeżenia Polska nie złożyła, a jesteśmy stroną porozumienia antydumpingowego już od 1981 roku”. Autor polemiki dodaje, że przepisy antydumpingowe istnieją w Polsce od 1989 roku, a nowa ustawa wprowadza tylko zmiany dostosowawcze do nowych standardów międzynarodowych, które zapewniają większą przejrzystość postępowań antydumpingowych, skrócenie terminów ich prowadzenia oraz jednolitość interpretacji terminologicznej. Za nietrafny uznał on pogląd profesora Kamińskiego, że wystarczającą alternatywą dla antydumpingu mogą być inne narzędzia ochrony rynku, stosowane w wypadku nieoczekiwanego wzrostu importu albo gwałtownego pogorszenia bilansu zagranicznego. Przyznał natomiast rację, że istnieje niebezpieczeństwo wykorzystywania przepisów antydumpingowych w celach innych, niż określone w WTO, ale takie zagrożenie ma charakter uniwersalny, bowiem stosowanie każdej regulacji prawnej narażone jest na deformację ${ }^{7}$.

5 Ibidem.

6 A. Pałafij, Antydumping - więcej strat niż korzyści, „Rzeczpospolita”, gazeta/Ekonomia, nr 291, 15 grudnia $1997 \mathrm{r}$.

7 Ibidem. 
Do zarzutów Macieja Leśnego i Adama Pałafija profesor Bartłomiej Kamiński ustosunkował się w kolejnym artykule ${ }^{8}$. Podtrzymał w nim tezę, że żaden artykuł WTO nie nakłada na sygnatariuszy obowiązku wprowadzenia ustaw antydumpingowych. W świetle natomiast przystapienia Polski do Unii Europejskiej, kwestia czy Polska przystąpi do UE z prawem antydumpingowym, czy też bez, nie rodzi implikacji prawnych ze względu na fakt, że to „Bruksela prowadzić będzie postępowanie antydumpingowe"s.

\section{Prawna regulacja postępowania antydumpingowego $w$ Polsce} - ustawa z dnia 24 sierpnia 2001 roku o ochronie przed przywozem na polski obszar celny towarów po cenach dumpingowych

Ustawa z dnia 11 grudnia 1997 roku o ochronie przed przywozem na polski obszar celny towarów po cenach dumpingowych (Dz. U. 1997, $\mathrm{Nr}$ 157, poz. 1028), której przyjęcie wzbudziło tak wiele kontrowersji, zastapiona została później przez ustawę z dnia 24 sierpnia 2001 roku o ochronie przed przywozem na polski obszar celny towarów po cenach dumpingowych (Dz. U. 2001, Nr 123, poz. 1352), trzykrotnie następnie zmienianą (Dz. U. 2002, Nr 41, poz. 365, Dz. U. 2002, Nr 125, poz. 1063, Dz. U. 2002, Nr 153, poz. 1271).

W myśl art. 1 ustawy z 24 sierpnia 2001 roku o ochronie przed przywozem na polski obszar celny towarów po cenach dumpingowych ${ }^{10}$ określa ona środki ochronne przed wyrządzającym szkodę przemysłowi krajowemu przywozem na polski obszar celny towarów po cenach dumpingowych oraz zasady i tryb postępowania w sprawie stosowania tych środków. Jeżeli krajem eksportu towaru będącego przedmiotem postępowania jest kraj będący członkiem Światowej Organizacji Handlu, środki antydumpingowe i postępowanie antydumpingowe określone w ustawie będą stosowane z zachowaniem wymogów określonych w Porozumieniu WTO o stosowaniu Artykułu VI w sprawie taryf celnych i handlu (tzw. Kodeks Antydumpingowy).

8 B. Kamiński, Czy ustawodawstwo antydumpingowe jest potrzebne. Powtórka z ekonomii, „Rzeczpospolita”, gazeta/Ekonomia, nr 12, 15 stycznia 1998 r.

9 Ibidem.

10 Dz. U. 2001, Nr 123, poz. 1352. 
Artykuł 3 Ustawy zawiera między innymi przyjęte w ustawie definicje szkody, przemysłu krajowego oraz środków antydumpingowych. Pod pojęciem szkody (art. 3 pkt 2) rozumie się istotną szkodę wyrządzoną przemysłowi krajowemu lub groźbę wyrządzenia istotnej szkody, czy też istotne opóźnienie w powstaniu przemysłu krajowego. Ustalenie szkody zgodnie $\mathrm{z}$ art. 17 ust. 1 omawianej Ustawy następuje natomiast na podstawie zebranego materiału dowodowego po dokonaniu oceny: 1) wielkości przywozu na polski obszar celny towarów po cenach dumpingowych oraz jego wpływu na poziom cen towarów podobnych na rynku krajowym oraz 2) wpływu tego przywozu na przemysł krajowy.

Przemysł krajowy według Ustawy (art. 3. pkt 3) to ogół producentów wytwarzających towar podobny na terytorium Rzeczypospolitej Polskiej lub tych spośród producentów, których łączna produkcja stanowi znaczącą część produkcji krajowej tego towaru. W przypadku natomiast, gdy producenci są powiązani z zagranicznymi eksporterami lub krajowymi importerami albo sami są importerami towaru będącego przedmiotem postępowania - przez przemysł krajowy można rozumieć pozostałych producentów krajowych wytwarzających towar podobny.

Środki antydumpingowe (art. 3 pkt 7 Ustawy) to tymczasowe i ostateczne cła antydumpingowe oraz zobowiązania cenowe (w rozumieniu przepisów prawa celnego tymczasowe i ostateczne cła antydumpingowe stanowią należności celne przywozowe). Zgodnie z art. 4 ust. 1 Ustawy mogą być one zastosowane wobec towaru objętego postępowaniem antydumpingowym jedynie wówczas, gdy w wyniku postępowania stwierdzono, że przez dopuszczenie towaru do obrotu na polskim obszarze celnym po cenie dumpingowej wyrządzana jest szkoda przemysłowi krajowemu. Towar uważa się za dopuszczony do obrotu na polskim obszarze celnym po cenie dumpingowej, jeżeli jego cena eksportowa jest niższa od wartości normalnej (art. 4 ust. 2).

Następnie ustawodawca w dziale II omawianej Ustawy określił między innymi pojęcia: wartości normalnej oraz marginesu dumpingu. Zgodnie z art. 6 ust. 1 Ustawy z dnia 24 sierpnia 2001 roku wartość normalną towaru objętego postępowaniem antydumpingowym ustala się, z zastrzeżeniem wyjątków przewidzianych w ustawie, na podstawie cen sprzedaży towaru podobnego, faktycznie zapłaconych lub należnych w zwykłym obrocie handlowym, gdy jest on przeznaczony do konsumpcji w kraju eksportu. Margines dumpingu (art. 12 ust. 1) stanowi natomiast kwotę, o jaką wartość normalna przewyższa cenę eksportową, przy czym porównywanie ceny eksportowej z wartością normalną dokonywane jest na tym sa- 
mym poziomie obrotu, zazwyczaj na poziomie cen zbytu producenta, w odniesieniu do transakcji sprzedaży dokonanych możliwie w jak najbardziej zbliżonych terminach oraz z uwzględnieniem różnic wpływających na porównywalność cen.

Postępowanie antydumpingowe wszczynane jest przez ministra właściwego do spraw gospodarki bądź na pisemny wniosek osoby fizycznej, osoby prawnej lub jednostki organizacyjnej nieposiadającej osobowości prawnej, złożony w imieniu lub na rzecz przemysłu krajowego bądź z urzędu - gdy zachodzą szczególne okoliczności, a posiadane dane i informacje wskazują na znaczne prawdopodobieństwo występowania dumpingu, szkody i związku przyczynowego między nimi (art. 24 ust. 1). Zgodnie z art. 26 minister właściwy do spraw gospodarki wydaje w ciagu 45 dni od dnia wpłynięcia kompletnego wniosku postanowienie o wszczęciu postępowania antydumpingowego po stwierdzeniu, że zgromadzone dane i informacje uprawdopodobniają przywóz na polski obszar celny towarów po cenach dumpingowych i wyrządzenie przez ten przywóz szkody. Postanowienie to powinno zawierać istotne informacje, które uzasadniaja podejrzenie występowania dumpingu, szkody oraz związku przyczynowego pomiędzy nimi.

Na podstawie materiałów dowodowych zgromadzonych w toku postępowania minister właściwy do spraw gospodarki dokonuje w drodze postanowienia, nie wcześniej niż na 2 miesiące i nie później niż na 6 miesięcy od dnia wszczęcia postępowania antydumpingowego, wstępnych ustaleń co do występowania dumpingu, szkody oraz związku przyczynowego pomiędzy nimi (art. 32 ust. 1). Postanowienie to jest następnie doręczane niezwłocznie władzom kraju eksportu oraz innym stronom, które zgłosiły swój udział w postępowaniu, przy czym stronom tym przysługuje w terminie 15 dni od dnia doręczenia postanowienia prawo do wniesienia zastrzeżeń co do wstępnych ustaleń (art. 32 ust. 3 i 4 omawianej Ustawy).

W toku postępowania antydumpingowego, po dokonaniu wstępnych ustaleń, lecz nie później niż na 2 miesiące przed upływem wyznaczonego terminu dla dokonania ustaleń ostatecznych, zagraniczny eksporter może wystąpić do ministra właściwego do spraw gospodarki z inicjatywą złożenia zobowiązania do zmiany cen lub do zaprzestania przywozu po cenach dumpingowych na polski obszar celny. Minister może wyrazić w drodze postanowienia zgodę na przyjęcie zobowiązania cenowego, jeśli jest ono wystarczające do usunięcia skutków dumpingu (art. 42 ust. 1). Po przyjęciu takiego zobowiązania minister właściwy do spraw gospodarki konty- 
nuuje postępowanie $\mathrm{w}$ celu ostatecznego ustalenia, czy miał miejsce przywóz towaru po cenach dumpingowych oraz czy wyrządzona została przez taki przywóz szkoda (art. 43 ust. 1 omawianej Ustawy). W przypad$\mathrm{ku}$, gdy minister stwierdzi naruszenie zobowiązania, wydaje w tym zakresie postanowienie, a następnie $\mathrm{w}$ drodze rozporządzenia ustanawia bądź tymczasowe cło antydumpingowe bądź ostateczne cło antydumpingowe (art. 46 ust. 1 i 3).

W trakcie postępowania antydumpingowego przedstawiciele krajowych organizacji konsumenckich lub przemysłu przetwarzającego towar objęty postępowaniem mogą przedstawiać informacje oraz opinie w sprawach istotnych dla toczącego się postępowania, w tym na temat interesu publicznego, któremu miałoby służyć zastosowanie środków antydumpingowych (art. 35 Ustawy).

Następnie na podstawie materiałów dowodowych zgromadzonych w toku postępowania minister właściwy do spraw gospodarki dokonuje w drodze postanowienia, nie później niż w terminie 6 miesięcy od dnia przyjęcia wstępnych ustaleń, ostatecznych ustaleń co do występowania dumpingu, szkody oraz związku przyczynowego pomiędzy nimi (art. 36 ust. 1). Postanowienie to zawiera ostateczne ustalenia dotyczące stanu faktycznego oraz prawnego, między innymi: powody, dla których odrzucono lub zaakceptowano argumenty, wnioski lub żądania eksporterów lub producentów, wysokość proponowanego cła antydumpingowego po uwzględnieniu interesu publicznego związanego z jego nałożeniem oraz po rozważeniu, czy cło mniejsze niż margines dumpingu wystarczyłoby do zlikwidowania szkody wyrządzonej przemysłowi krajowemu oraz uzasadnienie proponowanej wysokości cła antydumpingowego (art. 36 ust. 2).

Jeżeli w wyżej opisanym postanowieniu ustalono wstępnie istnienie dumpingu i będącej jego wynikiem szkody, minister właściwy do spraw gospodarki może w drodze rozporządzenia ustanowić tymczasowe cła antydumpingowe w celu zapobieżenia powstawaniu dalszej szkody w czasie toczącego się postępowania (art. 38 ust. 1). Tymczasowe cło antydumpingowe ustanawia się na okres 6 lub 9 miesięcy (art. 39).

Minister właściwy do spraw gospodarki w terminie 12 miesięcy (a w szczególnych przypadkach w terminie 18 miesięcy) kończy postępowanie antydumpingowe (art. 47 ust. 1):

- w przypadku wykazania w drodze ustaleń ostatecznych, że ma miejsce przywóz na polski obszar celny towarów po cenach dumpingowych i przywóz ten wyrządza szkodę, minister kończy postępowanie i usta- 
nawia w drodze rozporządzenia ostateczne cło antydumpingowe (art. 48). Cła antydumpingowe ustanawia się w wysokości niezbędnej do usunięcia szkody, ale nieprzekraczającej marginesu dumpingu (art. 53);

- w przypadku wykazania w drodze ustaleń ostatecznych, że przyjęte zobowiązanie cenowe nie jest wystarczające do usunięcia szkody wyrządzonej przez przywóz po cenach dumpingowych, minister może zaproponować zagranicznemu eksporterowi przyjęcie nowego zobowiązania cenowego, a odrzucenie tej propozycji będzie traktowane jak naruszenie zobowiązania cenowego (art. 49 ust. 1);

- poprzez umorzenie, gdy postępowanie z jakiejkolwiek przyczyny stało się bezprzedmiotowe (art. 51);

- niezwłocznie, w drodze postanowienia bez ustanowienia środka antydumpingowego:

a) w stosunku do kraju, z którego przywóz na polski obszar celny uznano za nieznaczny,

b) gdy nie stwierdzono, że ma miejsce przywóz na polski obszar celny towaru objętego postępowaniem antydumpingowym po cenach dumpingowych, który wyrządza szkodę przemysłowi krajowemu lub wyrządzona szkoda jest nieznaczna,

c) jeżeli margines dumpingu jest mniejszy niż $2 \%$ ceny eksportowej,

d) jeżeli wymaga tego interes publiczny.

Omawiana Ustawa reguluje również postępowanie w sprawie obejścia ceł antydumpingowych, postępowanie przeglądowe, weryfikacyjne, rewizyjne oraz zasady zwrotu ceł antydumpingowych.

\section{Regulacje antydumpingowe w Unii Europejskiej}

Najwcześniejsze regulacje GATT dotyczące dumpingu i antydumpingu zawarte w artykule VI - Cła antydumpingowe i wyrównawcze - były dosyć ogólne. W artykule VI.1 stwierdzono, że dumping „umożliwiający wprowadzenie towarów jednego kraju na rynek drugiego po cenie niższej od ich normalnej wartości, należy potępić, jeżeli powoduje poważne straty lub [...] stwarza groźbę takich strat, lub jeżeli poważnie opóźnia utworzenie odpowiedniego przemysłu krajowego". Produkt jest sprzedawany poniżej wartości normalnej, jeżeli cena jest:

a) niższa od ceny porównywalnej, stosowanej w normalnych stosunkach handlowych, podobnego produktu przeznaczonego na rynek wewnętrzny, 
b) w przypadku, gdy cena taka (normalna) nie istnieje, gdy cena eksportowa jest niższa od:

- najwyższej $[. .$.$] ceny produktu eksportowanego do trzeciego kraju$ $[\ldots]$,

- kosztów produkcji tego towaru w kraju jego pochodzenia, powiększonych o uzasadnioną marżę na koszty sprzedaży i zysk.

Należy przy tym każdorazowo uwzględnić różnice w warunkach sprzedaży, różnice w opodatkowaniu i inne różnice wpływające na porównywalność cen ${ }^{11}$.

Następnie w artykule VI.2 stwierdzono, że „w celu zneutralizowania dumpingu lub zapobieżenia mu każdy [kraj] może nakładać [...] cło antydumpingowe, nie wyższe od marży dumpingowej odnoszącej się do danego produktu. Marżę (margines dumpingowy) stanowi różnica pomiędzy wartością normalną a ceną eksportową. Główne pojęcia używane w artykule VI nie zostały jednak bliżej wyjaśnione ${ }^{12}$.

Artykuł XIX GATT zawierał klauzulę ratunkową, czyli możliwość zawieszenia zobowiązań w sytuacjach, w których $\mathrm{w}$ nieprzewidzianych okolicznościach rynek jednego państwa został dotknięty ,inwazją eksportową" innego państwa ${ }^{13}$.

Późniejsze zmiany dokonywane w ramach GATT służyły głównie sprecyzowaniu pojęć używanych w artykule VI i odzwierciedlały one dążenie do zmniejszenia możliwości nadużywania postępowań antydumpingowych dla celów protekcjonistycznych.

Końcowe Porozumienie o stosowaniu artykułu VI WTO jest wynikiem wielostronnego kompromisu. W myśl nowych zasad warunkiem umożliwiającym rozpoczęcie postępowania antydumpingowego jest równoczesne wystapienie: dumpingu, szkody materialnej, związku przyczynowo-skutkowego pomiędzy importem po cenach dumpingowych a szkodą materialną (art. 5.2) ${ }^{14}$.

W Porozumieniu WTO powtórzono definicję dumpingu, który oznacza występowanie różnicy pomiędzy wartością normalną a ceną eksportową (artykuł 2.1), przy czym wartością normalną jest zazwyczaj cena produktu w kraju eksportera. Cenę tę można stosować jedynie wtedy, gdy

11 J. Michałek, Polityka handlowa. Mechanizmy ekonomiczne i regulacje międzynarodowe, Wydawnictwo Naukowe PWN, Warszawa, 2002, s. 301.

12 Ibidem, s. 301.

13 B. Bernaś, op. cit., s. 166.

14 J. Michałek, op. cit., s. 302. 
podobny towar jest sprzedawany na normalnych warunkach na rynku wewnętrznym eksportera ${ }^{15}$. „Nienormalne” warunki są interpretowane jako długotrwała sprzedaż znacznych ilości po cenach nie gwarantujących pokrycia pełnych kosztów w rozsądnym czasie. Przyjęcie takiej zasady oznacza, że „zbyt” niskie ceny krajowe mogą być odrzucone, a w zamian importerzy mogą stosować wyższe wielkości (konstruowane), obrazujące wartość normalną. W przypadku odrzucenia ceny krajowej, jako wartości normalnej, można alternatywnie stosować cenę eksportową do kraju trzeciego lub cenę „konstruowaną"16.

Cena eksportowa jest podstawą do określenia marginesu dumpingu, jeżeli istnieje normalna sprzedaż na rynku trzecim i nie występuje domniemana zależność lub płatności transferowe pomiędzy eksporterem i importerem lub stroną trzecią (artykuł 2.3). Z kolei w przypadku użycia ceny „konstruowanej” winna ona odzwierciedlać koszt produkcji w kraju pochodzenia, powiększony o rozsądne koszty administracyjne, sprzedaży, koszty ogólne oraz zysk (artykuł 2.2), przy czym nie wyjaśniono nigdzie, jaka stopa zysku jest uznawana za rozsądną. W nowym porozumieniu sprecyzowano te pojęcia. Określono mianowicie sposoby przeliczania walut. Sprecyzowano też metody porównania cen przy określaniu marginesu dumpingu. Można wówczas porównywać średnie ważone wartości dla każdej transakcji oddzielnie i na tej podstawie określić średni margines dumpingu. W nowym porozumieniu określono również rodzaje kosztów, które winny być brane pod uwagę przy konstruowaniu ceny. Wymieniono tu zarówno koszty bezpośrednie produkcji, jak i koszty pośrednie - administracyjne. Wszystkie postanowienia dotyczą kosztów średnich produkcji, co różni się znacznie od argumentów związanych z teoretyczną analizą dumpingu (analizując modelowo funkcjonowanie przedsiębiorstwa maksymalizującego zysk, przy określaniu wielkości produkcji i ewentualnego dumpingu, bada się poziom kosztów krańcowych, a nie średnich) ${ }^{17}$.

Następne ważne uszczegółowienia dotyczą pojęcia szkody krajowego przemysłu (artykuł 3), przy czym termin ten jest interpretowany w trojaki sposób:

- materialna szkoda przemysłu krajowego,

15 Nie można jej również stosować wtedy, gdy występuje niski poziom sprzedaży na rynku kraju eksportera (poniżej 5\% sprzedaży eksportowej) lub szczególna sytuacja na tym rynku.

16 Ibidem, s. 302.

17 Ibidem, s. 302-303. 
- zagrożenie materialną szkodą,

- materialne opóźnienie ustanowienia krajowego przemysłu (to pojęcie związane z koncepcją protekcjonizmu wychowawczego, nie zostało w ogóle wyjaśnione).

Określone natomiast zostały kluczowe elementy związku pomiędzy szkodą materialną a importem na warunkach dumpingu. Jej oszacowanie wymaga określenia wielkości importu na warunkach dumpingowych oraz wpływu tegoż importu na krajowych producentów podobnych dóbr. Oceniając sytuację krajowych producentów, należy brać pod uwagę spadek popytu i zmiany zachowań konsumentów, zmiany technologiczne oraz wydajność przemysłu krajowego (artykuł 3.5$)^{18}$.

Z kolei przemysł krajowy jest interpretowany w artykule 4 jako „ta część producentów krajowych, których łączna produkcja stanowi znaczną część produkcji krajowej ogółem tych towarów". Wyjątkiem jest sytuacja, w której występuje powiązanie pomiędzy producentami krajowymi i importerami lub eksporterami produktu. Przemysł krajowy może też być utożsamiany z przemysłem regionalnym (artykuł 4.1ii). Definicja ta jest istotna, ponieważ wniosek o rozpoczęcie postępowania antydumpingowego może być skierowany jedynie ,przez lub w imieniu przemysłu krajowego, jeśli ma poparcie tych krajowych producentów, których łączna produkcja stanowi więcej niż 50\% globalnej produkcji [...]. Postępowanie nie może być jednak rozpoczęte, jeśli na krajowych producentów, wyraźnie popierających wniosek, przypada mniej niż 25\% globalnej produkcji podobnego produktu [...]", jak wynika z artykułu 5.4. Przyjęta definicja przemysłu krajowego jest zatem zbieżna $\mathrm{z}$ zapisami zawartymi w Porozumieniu w sprawie subsydiów $\mathrm{WTO}^{19}$.

Postępowanie antydumpingowe rozpoczęte na wniosek przemysłu krajowego winno być zawieszone zgodnie z unormowaniami zawartymi w artykule 5.8, jeżeli okaże się, że:

a) margines dumpingu jest znikomy (tzn. nie jest mniejszy niż $25 \%$ wartości eksportowej),

b) wielkość importu w warunkach dumpingu jest nieistotna (nie przekracza 3\% całości importu podobnego towaru).

Możliwa jest również tzw. kumulacja szkody - ma miejsce wtedy, gdy import każdego z krajów objętych postępowaniem jest nieznaczny (tzn.

18 Ibidem, s. 303.

19 Ibidem, s. 303. 
poniżej 3\%), ale ich łączny udział przekracza 7\%. Formuła ta była już wcześniej używana i jest często stosowana $\mathrm{w}$ odniesieniu do marginalnych dostawców z Europy Środkowo-Wschodniej ${ }^{20}$.

Przemysł krajowy składający wniosek o rozpoczęcie postępowania musi dostarczyć uzasadnienie, w którym winien wykazać związek przyczynowo-skutkowy pomiędzy dumpingiem i szkodą. Wniosek taki musi ponadto zawierać dane na temat wielkości produkcji krajowej, stosowanych cen krajowych i importowanych oraz rzekomego dumpingu (artykuł 5.2). Administracja kraju importera, rozpoczynając procedurę antydumpingową, musi powiadomić eksporterów lub producentów objętych postępowaniem oraz poprosić ich o informacje i odpowiedzi na temat rzekomego dumpingu. Informacje te winny być dostarczone w ciagu 30 dni i mogą być wykorzystywane z zachowaniem zasad poufności, przy czym administracja kraju importera może weryfikować ich prawdziwość. Procedury weryfikacji tych informacji zostały określone w załączniku I do porozumienia. Zgodnie z nim (artykuł 6.8), w przypadku, gdy strona objęta postępowaniem „odmawia dostępu do niezbędnych informacji lub w inny sposób ich nie udostępnia [...], wstępne, jak i ostateczne ustalenia mogą być dokonane na podstawie dostępnych informacji”. Z kolei zasady korzystania z tych informacji zostały określone w załączniku II, który stanowi, że korzystając z dostępnych informacji, zwłaszcza tych dostarczonych przez przemysł krajowy, należy to robić ze szczególną ostrożnością. Stwierdzono w nim ponadto, że ,jeśli zainteresowana strona nie współpracuje [...], to sytuacja taka może prowadzić do rozstrzygnięcia mniej korzystnego dla tej strony, niż gdyby współpracowała z władzami (kraju importera), 21 .

Po ustaleniu marży dumpingu władze kraju importera mogą nałożyć środki tymczasowe i/lub ostateczne, czyli cła antydumpingowe i zobowiązania cenowe. Środki tymczasowe, najczęściej w formie weksli gwarancyjnych, mogą być stosowane przez okres 4 miesięcy, po wstępnym ustaleniu szkody i dumpingu. Natomiast środki ostateczne są nakładane po udowodnieniu dumpingu i szkody. Ich poziom nie może przekraczać marży dumpingu. Eksporterzy objęci postępowaniem antydumpingowym mogą podjąć zobowiązania cenowe, których akceptacja przez administrację kraju importera winna zakończyć postępowanie. Przyjęte ceny mini-

20 Ibidem, s. 303.

21 Ibidem, s. 303-304. 
malne winny być w miarę możliwości niższe od cen eksportowych powiększonych o margines dumpingu. Zobowiązania cenowe zmniejszają presję konkurencyjną i możliwość wystąpienia szkody krajowego przemysłu. Są one bardziej korzystne niż cła antydumpingowe dla tych eksporterów, którzy rzeczywiście stosowali dumping. W tym bowiem przypadku wielkość wyliczonego cła antydumpingowego może być przyjęta przez eksportera, jeśli tylko będzie on w stanie utrzymać się na rynku. Władze kraju importera mogą jednak nie przyjąć zobowiązania cenowego, przy czym przyczyny odmowy winny zostać uzasadnione. Z kolei cła antydumpingowe powinny być pobierane od wszystkich eksporterów, którym udowodniono dumping, a ich wielkość nie powinna przekraczać wyliczonej marży. Cła antydumpingowe i zobowiązania cenowe powinny być automatycznie wycofane po upływie 5 lat od momentu ich wprowadzenia (sunset clause). Ich stosowanie może być jednak wydłużone o dalsze 5 lat po odpowiedniej weryfikacji. Zapis ten został wprowadzony dopiero w Porozumieniu WTO i był postulowany przez kraje szczególnie dotknięte prowadzonymi w stosunku do nich postępowaniami antydumpingowymi ${ }^{22}$.

Nakładanie ceł antydumpingowych wiąże się często z dwiema trudnymi kwestiami. Pierwsza z nich to zwrot nadpłaconego cła. W nowym porozumieniu ustalono, że cła mogą być nakładane z mocą wsteczną (jak w USA), lub prospektywnie (tj. dla okresu przyszłego, jak w Unii Europejskiej). Obie metody zostały uznane za poprawne (artykuł 9.3) i określono limity czasowe na zwrot nadpłaconych sum. Jest to sukces eksporterów, którzy w GATT otrzymywali zwroty nadpłaconych sum z dużym opóźnieniem, co zwiększało ich koszty handlowe. Drugim problemem jest wymierzanie cła antydumpingowego eksporterom nie objętym bezpośrednio postępowaniem. W przeszłości nakładano niekiedy tzw. cło rezydualne, czyli najwyższe spośród zastosowanych wobec eksporterów objętych postępowaniem. W myśl nowego porozumienia (artykuł 9.4), cło nakładane nie może być wyższe od: a) średniej ważonej marginesu dumpingu określonego względem wybranych eksporterów lub producentów, b) jeżeli płatność jest obliczona na podstawie prospektywnej wartości normalnej, różnicy między średnią ważoną wartości normalnej wybranych eksporterów lub producentów i cen eksportowych eksporterów lub producentów nie objętych badaniem [...]. Ten system naliczania cła winien zmniejszyć

22 Ibidem, s. 304. 
skalę nieuzasadnionej dyskryminacji celnej producentów bezpośrednio nie objętych postępowaniem antydumpingowym ${ }^{23}$.

W Porozumieniu WTO sprecyzowano również główne kwestie proceduralne oraz określono wymogi dotyczące niezbędnej dokumentacji w każdej fazie postępowania antydumpingowego, zasady weryfikacji i wizytacji eksporterów lub producentów, limity czasowe poszczególnych etapów oraz procedury rozwiązywania kwestii spornych. Nowe Porozumienie zawiera więc wiele kwestii technicznych, które winny zmniejszyć skalę nadużywania postępowań antydumpingowych w celach protekcjonistycznych. Sama natomiast istota prawna interpretacji dumpingu, który zawsze traktowany jest jako forma nieuczciwej konkurencji i powinien być zwalczany, pozostała niezmieniona. A interpretacja ta może być kwestionowana na gruncie opisanej wcześniej analizy ekonomicznej tego zjawiska. Należy również nadmienić, że pewne kluczowe kontrowersyjne kwestie nie zostały rozstrzygnięte - brak nadal definicji środków zapobiegających „obchodzeniu” postępowań antydumpingowych (tzw. anticircumvention) i nie zdefiniowano do tej pory np. pojęcia „rozsądny zysk”. Należy przy tym pamiętać, że formułowanie kryteriów ilościowych ułatwia wprawdzie interpretację prawną, ale może być podważane na gruncie analizy ekonomicznej ${ }^{24}$.

Kraje należące do WTO zostały zobowiązane do wdrożenia zasad Porozumienia $\mathrm{w}$ sprawie stosowania art. VI WTO $\mathrm{w}$ ramach narodowej legislacji. Unia Europejska uczyniła to z dniem 1 stycznia 1995 roku na mocy Rozporządzenia Rady WE nr 384/96 oraz poprawek do tego Rozporządzenia. Obok drobnych modyfikacji dodano dwa dodatkowe elementy, nie występujące explicte w Porozumieniu WTO. Pierwszy z nich dotyczy tzw. interesu Wspólnoty. Punktem wyjścia, podobnie, jak w Porozumieniu WTO, jest wystąpienie dumpingu, szkody dla przemysłu krajowego oraz związku przyczynowo-skutkowego pomiędzy pierwszym i drugim ${ }^{25}$. Różne postaci dumpingu mogą wywierać niekorzystny wpływ na ekonomikę Wspólnoty przez wzrost sprzedaży importowanych produktów, spadek produkcji przedsiębiorstw wspólnotowych, ograniczenie zysków producentów wspólnotowych, wzrost bezrobocia. Jeśli więc Rozporządzenie 384/96 wymaga, iż postępowanie antydumpingowe musi być prowadzone w interesie Wspólnoty, oznacza to, iż musi ono rozważyć

23 Ibidem, s. 305.

24 Ibidem, s. 305.

25 Ibidem, s. 306-307. 
jedną z wymienionych wyżej szkód, poniesioną przez producentów wspólnotowych lub konsumentów i dopiero wówczas nałożyć na obciążony dumpingiem towar odpowiednią sankcję, która ostatecznie może przybrać postać opłaty antydumpingowej ${ }^{26}$. Oznacza to w praktyce, że nałożenie cła antydumpingowego może zostać zakwestionowane przez reprezentację konsumentów korzystających z niższych cen, nawet jeżeli import taki wywołuje szkodę krajowych producentów podobnego towaru ${ }^{27}$. J. Justyński wskazuje jednak, że w orzeczeniu, które zapadło w sprawie C-156/87 Gestetner Holdings plc v. EC Council and EC Commission (1990) ECR I-781, I-843, Europejski Trybunał Sprawiedliwości argumentował, iż na plan pierwszy wysunąć należy konieczność ochrony przemysłu Wspólnotowego i dać jej prymat przed interesem konsumentów ${ }^{28}$. Podobnie wdrożenie środków antydumpingowych może zostać zakwestionowane przez użytkowników półfabrykatów importowanych po cenach dumpingowych, ale wywołujących szkodę dla producentów krajowych podobnych półfabrykatów. Drugie specyficzne rozwiązanie dotyczy sposobów zapobiegania „obejścia” przepisów antydumpingowych. Zgodnie z legislacją środki antydumpingowe można nałożyć na produkty lub ich części podlegające cłu antydumpingowemu, jeśli nie były one płacone w wyniku oszustw celnych lub podjęcia działalności montażowej na terenie UE lub krajów trzecich ${ }^{29}$. Firmy eksportujące mogą bowiem próbować uchylić się od działań antydumpingowych, tworząc zakłady montażowe w kraju importera, gdzie produkt finalny został obłożony cłem antydumpingowym, albo w kraju trzecim ${ }^{30}$.

Obok tego Unia stosuje pewne procedury, które nie zostały bezpośrednio zdefiniowane czy omówione w Porozumieniu WTO. Po pierwsze, Komisja może ponownie otworzyć postępowanie, jeśli eksporter „zrekompensował” sobie nałożenie cła. Dotyczy to zjawiska „wchłonięcia cła” lub pełnej ,incydencji celnej”. W takim przypadku nie występuje oczekiwany wzrost cen eksportowych danego producenta na rynku UE.

26 J. Justyński, Podstawy prawne polityk gospodarczych Unii Europejskiej, TNOiK, Toruń, 2001, s. 212.

27 J. Michałek, op. cit., s. 307.

28 J. Justyński, op. cit., s. 212.

29 J. Michałek, op. cit., s. 307.

30 B. Hoekman, M. M. Kostecki, Ekonomia światowego systemu handlu.WTO: Zasady i mechanizmy negocjacji, Wydawnictwo Akademii Ekonomicznej im Oskara Langego we Wrocławiu, Wrocław 2002, s. 305-306. 
Byłby to przypadek, w którym kraj importer (UE) zwiększył swój poziom dobrobytu poprzez uzyskanie dochodów fiskalnych z zastosowanych ceł antydumpingowych, a pomimo tego chce zastosować środki ograniczające import w celu ochrony krajowych producentów. Drugi przypadek dotyczy zjawiska tzw. podcięcia cen (price undercutting), czyli sytuacji, w której znaczny import po zaniżonych cenach, powodujący względny spadek udziału przemysłu unijnego w rynku wewnętrznym prowadzi do spadku ceny producentów UE, przy czym podejście to może być zastosowane dopiero wtedy, kiedy stwierdzono, że dumping miał rzeczywiście miejsce $^{31}$.

Przepisy antydumpingowe należą do najczęściej stosowanych środków ochrony rynku UE. Pod względem formalnym procedurą antydumpingową w Unii zajmują się 3 instytucje: Komisja Europejska, Rada Unii Europejskiej oraz Komitet Doradczy. W praktyce najważniejszą rolę odgrywa jednak Komisja. Podejmuje ona decyzje w sprawach wszczęcia postępowania antydumpingowego, przebiegu dochodzenia i jego wyników $^{32}$. Przepisami wewnętrznymi regulującymi procedurę antydumpingową Wspólnoty są: Zarządzenie Rady nr 2026/97 z 6 października 1997 roku, które zastąpiło Zarządzenie nr 2423/88 oraz Decyzja Komisji nr 2424/88/ECSC z 29 lipca 1988 roku.

\section{Co się zmienilo po akcesji?}

Po przystąpieniu Polski do Unii przestały obowiązywać polskie przepisy regulujące obrót $\mathrm{z}$ zagranica, $\mathrm{w}$ tym ustawa antydumpingowa. Zastapione zostały przez wyżej opisane wspólnotowe regulacje prawne. Kompetencje w zakresie ustanawiania instrumentów administrowania obrotem z krajami trzecimi i w zakresie środków ochronnych zostały przejęte przez właściwe instytucje UE, a Polska uczestniczy w procesie decyzyjnym UE poprzez swoich przedstawicieli w Komitecie Doradczym, jak również poprzez udział w głosowaniu w Radzie UE. Prowadzenie polityki handlowej przez organy Wspólnotowe będzie niewątpliwie korzystne dla Polski, jeśli chodzi o doświadczenie, skuteczność podejmowanych działań, rozwiązywanie sporów handlowych na forum WTO czy

31 J. Michałek, op. cit., s. 307.

32 Z. W. Puślecki, System środków kontroli handlowej Unii Europejskiej w warunkach globalizacji, Wydawnictwo Naukowe UAM, Poznań 2001, s. 118. 
ewentualne procesy sądowe. $\mathrm{Z}$ drugiej jednak strony polityka ta, będąca wypadkową interesów poszczególnych państw członkowskich, nie zawsze będzie odpowiadała interesom Polski. Polska nie będzie także mogła wykorzystywać instrumentów polityki handlowej do retaliacji czy wywierania nacisku na swych partnerów handlowych w celu ograniczenia ich działań protekcjonistycznych ${ }^{33}$.

W momencie uzyskania członkostwa środki antydumpingowe i ochronne obowiązujące $\mathrm{w}$ imporcie do Polski zostały zniesione, zaczęły natomiast obowiązywać środki ustanowione przez Unię, które w niektórych przypadkach będą korzystne dla polskich producentów. Należy się jednak liczyć z możliwością wystąpienia odmiennych preferencji ${ }^{34}$. Według szacunków, w chwili akcesji w imporcie do UE obowiązywało cło antydumpingowe na około 60 produktów z ponad 20 krajów i cło wyrównawcze na kilkanaście towarów z 8 krajów azjatyckich, przy czym należy się liczyć z tym, że nałożone środki nie będą stanowiły ochrony dla polskiego przemysłu, a jedynie dodatkowy koszt dla konsumentów. Rezygnacja z procedur antydumpingowych ze względu na asymetrię w ich stosowaniu, jest korzystna dla Polski w świetle faktu, że w okresie stowarzyszenia ze Wspólnotami Europejskimi Polska wszczęła tylko jedno postępowanie w sprawie importu z państwa członkowskiego, podczas gdy Unia - dwanaście nowych postępowań. Postępowania wszczynane wobec Polski przez UE dotyczyły wprawdzie niewielkiej części polskiego eksportu na ten rynek, jednak dla konkretnych eksporterów skutki wszczęcia postępowania i nałożenia środków antydumpingowych były zazwyczaj dotkli$\mathrm{we}^{35}$.

Na zakończenie należy podkreślić, że niestosowanie procedur antydumpingowych $w$ handlu wewnątrz UE nie jest tożsame $\mathrm{z}$ faktem, że polskie firmy zostaną pozbawione prawnych możliwości ochrony przed dyskryminacyjnymi praktykami cenowymi. Nieuczciwa konkurencja cenowa w stosunkach pomiędzy polskimi przedsiębiorstwami a unijnymi będzie bowiem podlegać wspólnotowym regułom konkurencji ${ }^{36}$.

33 E. Kaliszuk, Ograniczenia pozataryfowe w imporcie i eksporcie Polski w świetle członkostwa w UE, w: praca pod red. J. Kotyńskiego, Zagraniczna polityka gospodarcza Polski 2002-2003, Instytut Koniunktur i Cen Handlu Zagranicznego, Warszawa 2003, s. 139.

34 Ibidem, s. 139.

35 Ibidem, s. 140-141.

36 Ibidem, s. 141. 


\section{Summary}

Passing of the Law of December 11, 1997 on protection of the Polish customs zone from the merchandise imported at dumping prices (Journal of Law 1997, no. 157, section 1028) raised considerable controversy among economists and stimulated a discussion on the principle of anti-dumping regulations coming into force as Poland was about to access the European Union.

The paper discusses the Polish anti-dumping regulations stipulated in the above Law of December 11, 1997 that were binding until the accession day and the changes introduced with respect to anti-dumping regulations following Poland's accession to the European Union. 